Historic, Archive Document

Do not assume content reflects current scientific knowledge, policies, or practices. 



\section{Flowering Trees of the Orient}
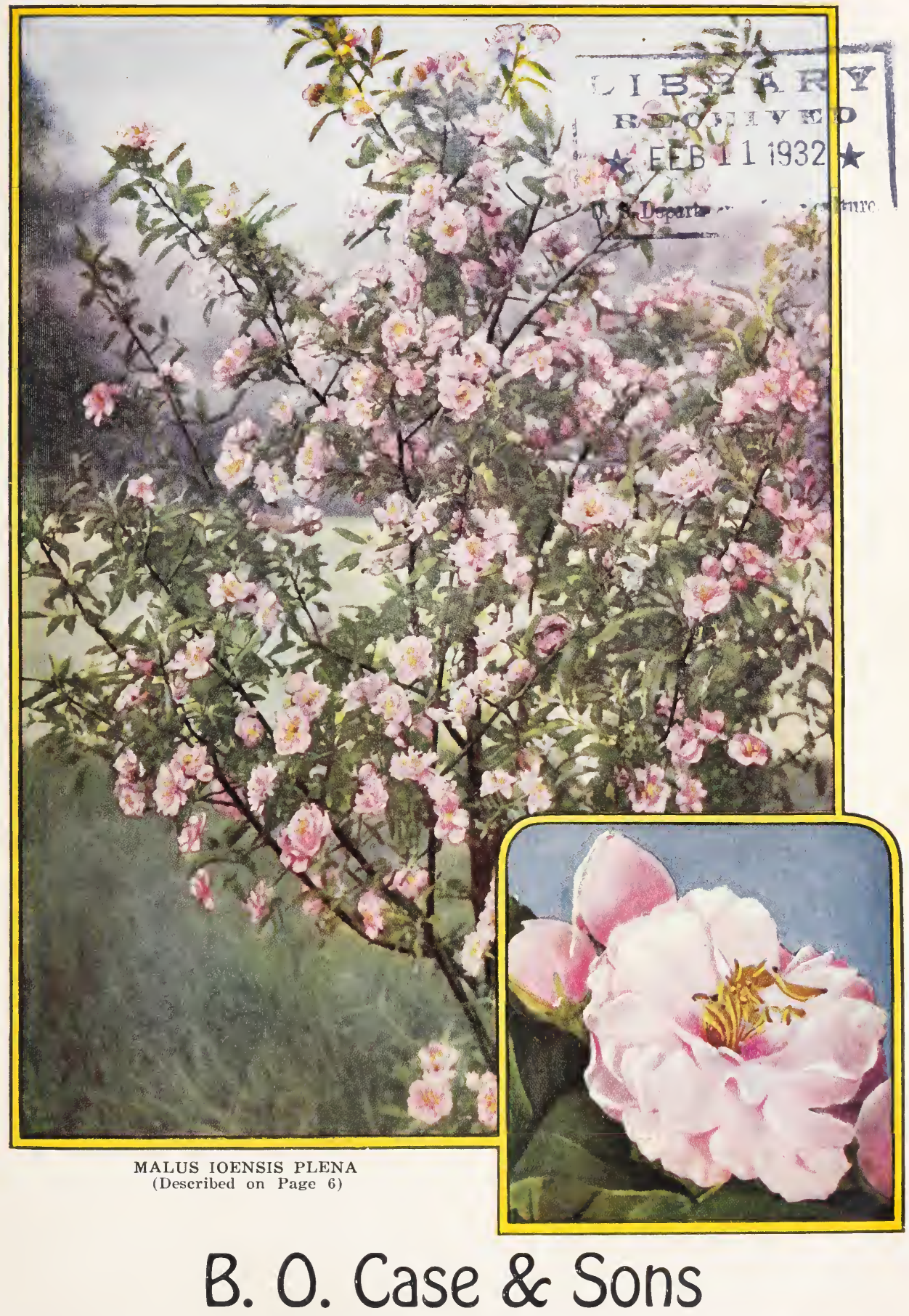


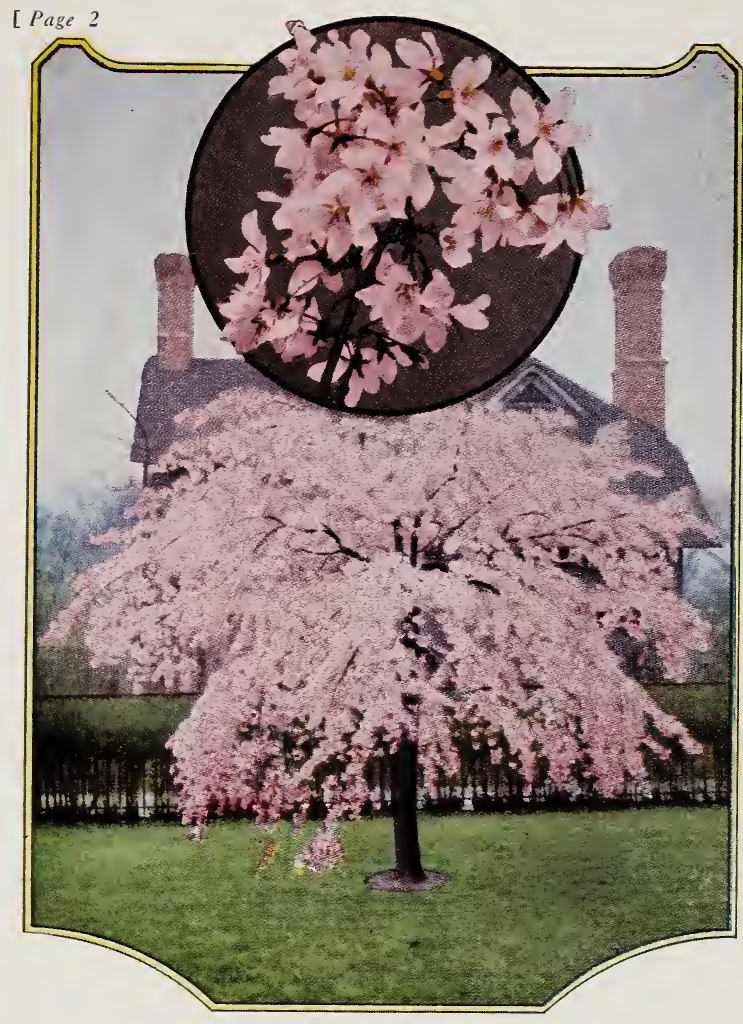

\section{If You Are Interested in the Rare, the Delightful. the Beautiful, Uisit Our Nursery}

\section{A Living Catalog of Choice Plants}

At our nurseries can be found just those delightfully different things which will add character and refinement to your plantings. Here you may study and select at leisure, among the choicest of French Hybrid Lilacs, the Flowering Trees of China and Japan, and rare shrubs of the whole world.

Your business judgment as well as your good taste will be satisfied by a visit to our nurseries. For the very choicest varieties, some so new that they are not yet available through other channels, you will have to pay but "one-profit," reasonable prices. And the quality of the stock, as you will be satisfied after once seeing it, is as fine as can be found anywhere.

Herewith we extend to you our cordial invitation to stop in and see us. If you are not ready to buy, or have not made up your mind as to exactly what you want, do not let that deter you-stop in and "look around" any-

SUBHIRTELLA PENDULA (Described on Page 6)

\section{WE PAY THE FREIGHT}

We prepay the freight, express or postage on all shrubs, trees, etc., under 3 feet in height if payment for the merchandise accompanies the order. All larger sizes will be sent collect.

\section{NOTICE TO FANCIERS}

We now have growing in our nursery 240 varieties of the French Hybrid Lilaes and more next stason. Anyone wishing a complete collection, please write. One hundred and eight thousand people visited the park in Rochester, N. Y., on "Lilac Day" last spring to admire a similar collection. We can also furnish 35 varieties of the Japanese Flowering Cherries, 23 varieties of Flowering Crabs, and 10 varieties of Flowering Peaches.

For larger Specimen Trees, please state your wants.

\section{YOUR GUARANTEE AND OURS}

Here's the proof that you, too, will be pleased with each purchase. Hundreds of orders have been shipped each season and not a disappointed customer to date. Not a kick in a trainload. Each order receives intelligent personal service. Our new business is largely made by our pleased cus. tomers telling others where the unusual things are grown. We employ no salesmen.

TERMS: Please send cash with order. We would rather give you bargains than have to keep books.

SHIPMENTS: Please give explicit shipping directions.

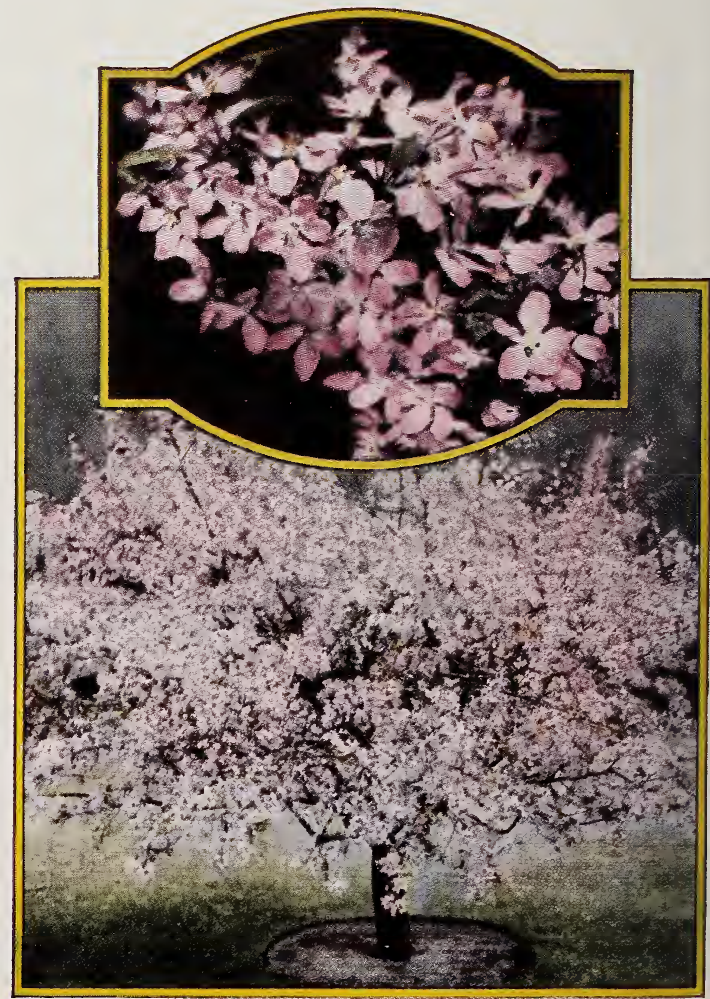

MALUS WAH MEE (Described on Page 6) 


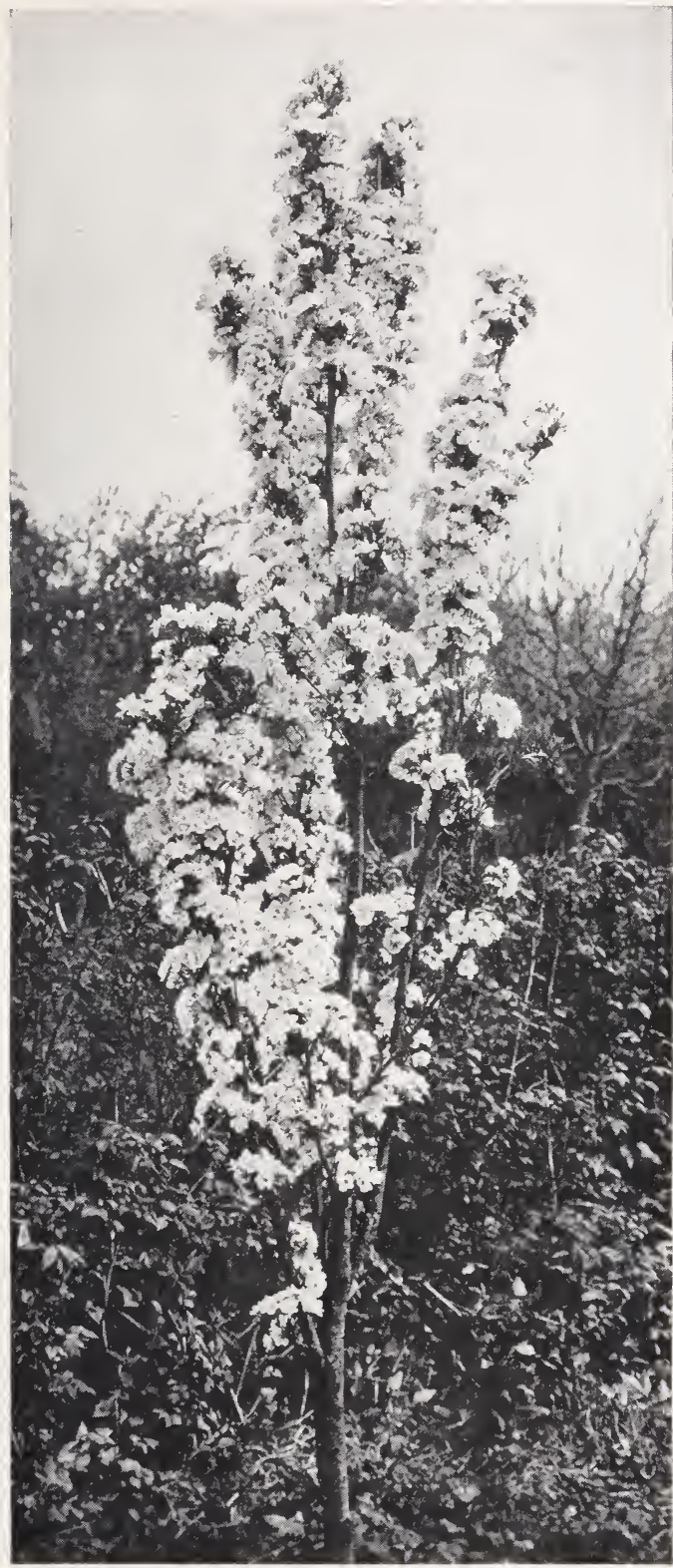

AMANOGAWA Fourth Year from the Nursery.

\section{Japanese Flowering Cherries}

Somewhere in the dim and distant past in the history of Japan, the cherry became established as its favorite flower. E. H. Wilson, author of "America's Greatest Garden," who spent two years in Japan studying and classifying the cherries, says:

"According to Japanese folklore, the cherry tree itself was a lovely princess named Konohama Sakura, reincarnate, the color of the petals being that of the blushes which diffused the cheeks of this bewitching damsel. From this pretty legend is derived the name Sakura or Zakura, now universally applied to the cherry tree in Japan. Today throughout the length and breadth of Japan, cherries are planted and growing in temple grounds, parks and courtyards, in palace gardens and in the gardens of the humble cottagers, as well as along the roadsides and streets of the greater cities. In the immediate vicinity of Tokyo it is estimated there are 50,000 of these trees. These trees, when in flower, are the call for the Cherry Blossom Festival throughout the length and breadth of Japan."

There are 2000 of these trees in Washing. ton, D. C., and excursion trains are run from every direction, as far as Ohio, when they are in bloom. Possibly this gives some idea of the attraction that some of these fastgrowing trees will give to our own gardens.

Amanogawa Sakura. Translated, means "Heaven's River" or "Milky Way." One of the very choicest varieties. No matter how small one's garden, there is room for this tree, as it takes up practical. ly no space at all, growing tall and slender like a miniature Lombardy Poplar. The blossoms are semi-double, a beautiful pink, on upright, short, stocky stems that give a charming effect as they cover every branch and twig. The flowers exhale a delicate fragrance. We recommend this as one of the gems of the collection.

3 to 4 ft., $\$ 2.75 ; 5$ to $6 \mathrm{ft} ., \$ 3.75$

Albo-Rosea Sakura (Cerasus). The picture of this beautiful tree is shown on Page 4. In form, this tree grows wide and almost drooping. The flowers are extremely large, up to $2 \frac{1}{2}$ inches in diameter. They are borne on racemes of 3 to 5 on long stems. The coloring is outstanding even among the cherries. The buds and blossoms are a very double pink, later becoming nearly cream, then again turning to cerise and lasting a whole month. During this time, as the new buds continue to open, the tree is a dazzling delight with buds and blossoms of pink, blossoms of cream and blossoms of cerise, all at the same time.

3 to $4 \mathrm{ft} ., \$ 3.00 ; 6$ to $7 \mathrm{ft} ., \$ 3.75$

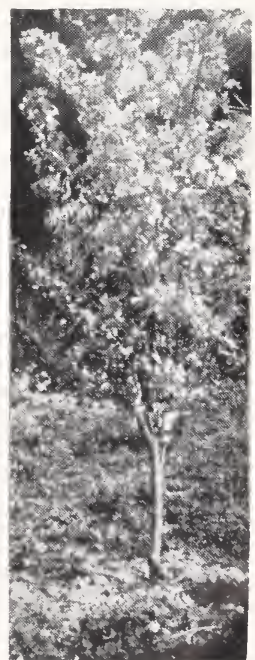

(Described on Page 6)
MALUS ELEYI 


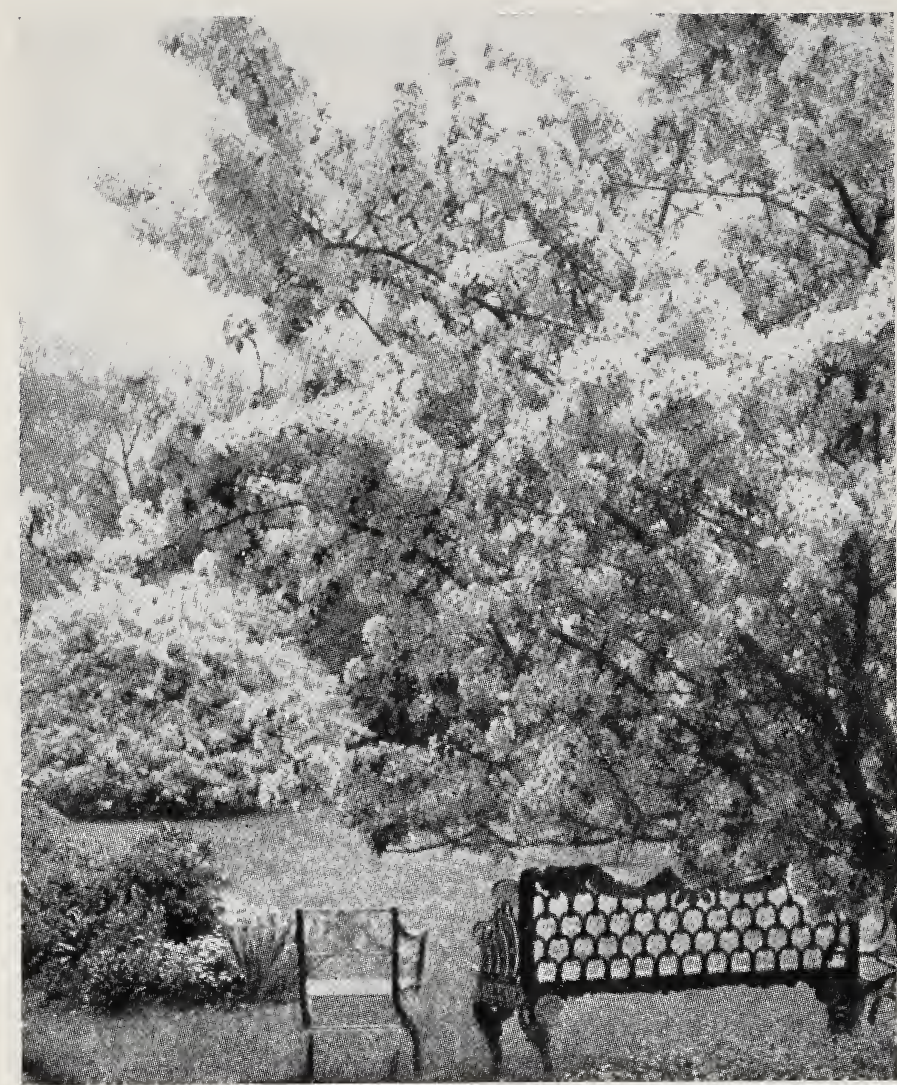

Shrub shown above is MALUS ARNOLDIANA Flowering Crab

Tree shown above is ALBO ROSEA (CERASUS) Flowering Cherry
Kwanzen Sakura. This form blooms later. It is graceful in form, has flaming red buds which open into deep pink, almost red double blossoms. They are large and rich. Most profuse in bloom. Mr. E. H. Wilson says: "To my mind it is the handsomest of all Japanese double-flowering cherries." $21 / 2$ to $3 \mathrm{ft} ., \$ 2.00 ; 6$ to $7 \mathrm{ft} ., \$ 3.75$

Kofugen Sakura. Translated, it means "Pink Saint." A much taller and thriftier tree than other double-flowering trees. A splendid tree for a larger space, parking or street planting. It has beautiful pink rose-like double blossoms on long stems.

2 to 3 ft., $\$ 2.00 ; 6$ to 7 ft., $\$ 3.75$

Mt. Fuji, Sirotae Sakura. Flowers pure white, double, large and fragrant. This is the finest of all the double flowering white cherries.

2 to 3 ft., $\$ 2.00$

Mikuruma Sakura. This name signifies one turns back after passing to take a farewell look. A very double rosecolored form with pendulous flowers of from 3 to 5 on a single stem. It blooms somewhat ahead of the other varieties and it has little competition at that time. It appears to be when in bloom the most popular of all.

6 to 7 ft., $\$ 3.50$

Prunaria Sakura. This variety is rather dwarf in growth, very upright, and it makes a splendid small garden tree. It blooms at the same time as the fruit cherries and by contrast makes them "look like 15c." The blossoms are entirely double and in color pinkish old rose blended with creamy white. It is a real gem. 4 to 5 ft., $\$ 3.75$
Autumnalis, Jugetzu Sakura. A wonderful flowering cherry. It blooms in March and again in October. Known in Japan as Chigo-Higan Sakura, meaning double pink flowering Spring Cherry.

2 to 3 ft., $\$ 2.00$

Beni Higan Sakura (Spring Cherry of Japan). The first of the cherries to bloom in early spring. Blossoms are small, light pink and single, but produce in multitudes absolutely covering the tree. It is a low branched shrub-like tree with the twiggy branches so intermingled that one can barely see through it even when the foliage has fallen. A veritable bird thicket. See cut, Page 7 .

$$
5 \text { to } 6 \text { ft., } \$ 1.75
$$

Fairy Queen, Shogetzu Sakura. The Japanese name signifies "Moonlight Through the Pines." Flowers pale pink, double and very large, on long pedicels; a late bloomer, it is at its best planted in a hedgerow where it blends beautifully in the landscape, as shown in cut on Page 6.

2 to 3 ft., $\$ 2.00$

Fugenzo Sakura. One of the most beautiful of all. The buds are crimson; the double flowers are deep pink, almost red, later fading to rose-pink. It stays long in bloom. Rare and desirable. See cut on page 6 .

6 to 7 ft., $\$ 3.75$

Hollandi Rosea. A splendid cherry; flowers very double, decidedly pink and grow in dense clusters.

5 to $6 \mathrm{ft} ., \$ 3.75$

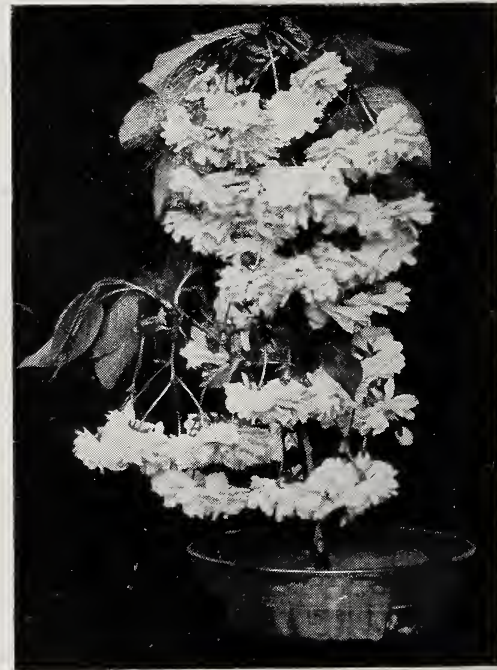

MIKURUMA SAKURA 


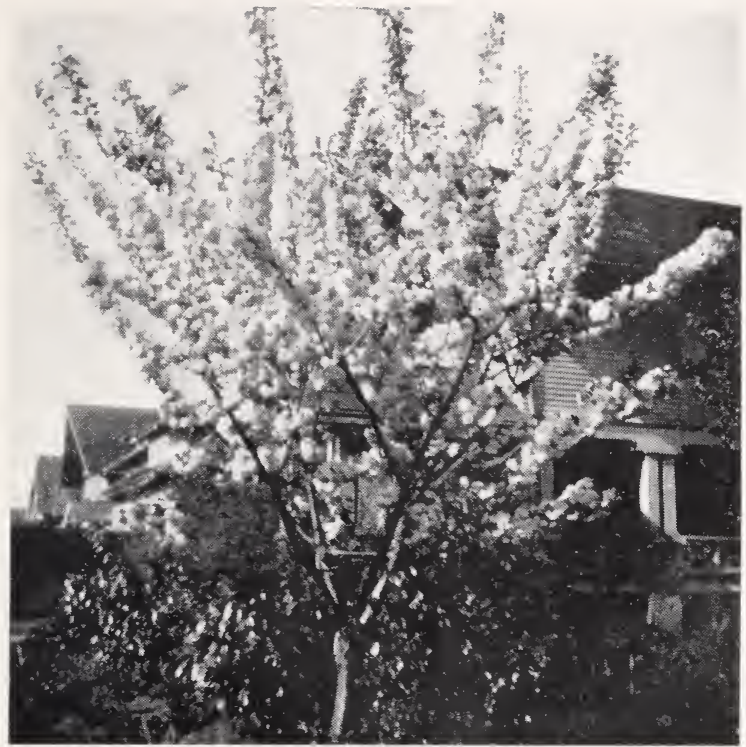

KWANZEN SAKURA

Pubescens Sakura. Flowers single, pale pink and rather small. A curious cherry which blooms in late winter grows to $30 \mathrm{ft}$, or more. 3 to $4 \mathrm{ft}$., $\$ 1.75$

Taizanfuken Sakura. A tall, slender, upright tree, almost as slender as Amanogawa. Flowers pink, of medium size and moderately double, mostly in clus. ters at end of each shoot.

2 to $3 \mathrm{ft} ., \$ 2.00$

Takasaga Sakura (Wilson's Naden). A very dwarf (probably 15 feet), upright tree. This is an ideal garden variety, gorgeous in bloom. Flowers are light pink on rather short stems and masses into large, compact clusters, as shown in the illustration. It blooms very early and, like most others, before the leaves appear. It is very showy and can be put into the smallest garden without crowd ing other plants.

$$
21 / 2 \text { to } 3 \mathrm{ft} ., \$ 1.75 ; 5 \text { to } 6 \mathrm{ft} ., \$ 2.75
$$

Ckon sikura. The most striking nov elty of the clierry family. Flowers yel low, tinged wit h green, quite double and borne in great profusion. trees in the vicinity of Tokyo are of this variety. When they bloom, it is the call for the Cherry Festival. The tree is quick growing and attains 30 to 40 feet in height; the branches are thick and wide-spreading, and form a broadly oval flattened head. The flower's are produced in clusters before the leaves and in color are white to pink and pinkish-white. It is one of the most floriferous of all, and for parking and street planting has no equal.

\section{Flowering Crabapples}

The mention of the word "crabapple" brings to mind fruit, and subsequently jelly and preserves, and explains why the beautiful flowering crabapple is not included in every city garden planting. This is because they are so little known, as the two distinct seasons of beauty extending over half the year would alone make them invaluable to the city gardener. No sooner has the

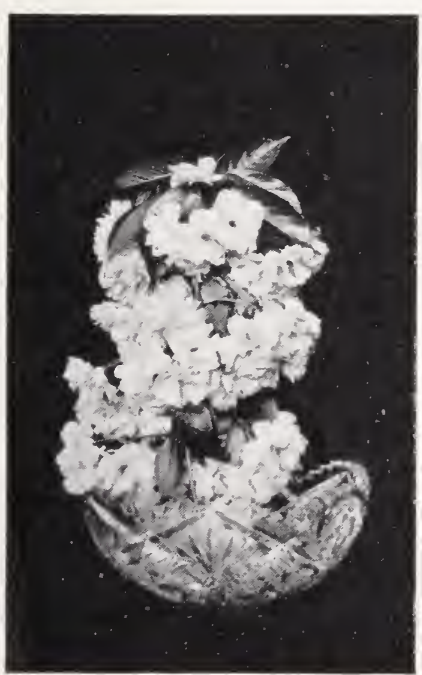

HOLLANDI ROSEA SAKURA
2 to $3 \mathrm{ft} ., \$ 2.00$

loshino Sakura. Nost of the 50,000

3 to $4 \mathrm{ft} ., \$ 1.75 ; 6$ to $; \mathrm{ft.}, \$ 2.00$ Howering season ended than the tree is
covered with myriads of tiny bright - colored fruits. The abundance of flowers and fruit produced by this shrub is truly astonishing and few, if any, plants give as

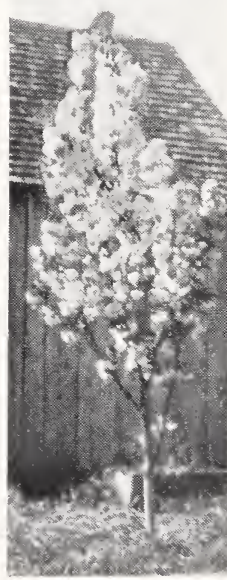

PRUNARIA SAKURA lotted in the garden. They are rugged in constitution and are able to withstand heat or cold without injury and are much hardier than the ordinary apple.

The crabs in flower have few rivals and are classed with the most gorgeous spring flowering trees and shrubs. The oriental varieties produce solid masses of blossoms before the leaves ap pear and in color extend from the purest white, through all the shades of pink, to the real carmine red, several having purple and reddish-purple blossoms. They require little care and, when planted singly or in masses, give remarkable results in a short time. Their use is not limited to the lawn. as they are in their greatest splendor when used on a large scale in woodland hor ders, open forest parks, golf grounds, roadsides or parking strips.

Malus Irnoldiana. Originated at the Arnold Arboretum. It is really a shrub, the branches falling over like a spirea. It flowers in masses of large pink blossoms on 3-inch red wirelike stems, later has myriads of tiny vellow apples. Ranks highest of its type. Specimen Trees, 4 to 5 ft., \$2.50

Malus Mldenhamensis. Originated in Aldenham, England. Flowers single, deep red, 1 inch in diameter, followed with dark red globose fruits. Word came to us that in the writer's opinion it was the "Handsomest tree in all England." New and rare.

1 to $2 \mathrm{ft} ., \$ 1.25 ; 4$ to $5 \mathrm{ft} ., \$ 2.75$ 


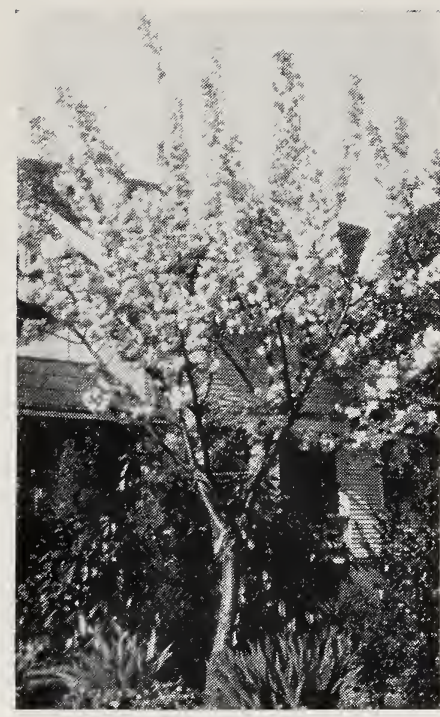

FUGENZO SAKURA

Malus Dolga. A new distinctive crab with brilliant red, edible fruit in great profusion; flowers bright red.

1 to 2 ft., \$1.00; very fine trees, 4 ft., $\$ 1.25$

Malus Eleyi. Award of Merit, R.H.S., London. A new and startling hybrid. A branchy fast-growing tree. In early spring the foliage comes out a brilliant red, the reddest of any, which gradually turns bronze. It has single purple flowers, and $\mathrm{Mr}$. A. E. Wohlert says: "It is exceedingly prolific and this variety has been considered the best." In autumn the fruit, the size of cherries, hang in dense clusters from the branches. The fruit is bright red and they hang on until winter.

1 to 2 ft., $\$ 1.00 ; 4$ to 5 ft., $\$ 1.50 ; 6$ to 7 ft., $\$ 2.50$; Specimens, $\$ 3.50$

Malus Floribunda. Bright pink flower buds, white flowers with pink still showing; yellowish fruits much relished by birds.

3 to 4 ft., $\$ 1.25$

Malus Goi Toi (Parkmani). Goi Toi means "The Tears of the Dragon." Semi-double pink, a dwarf tree very slow of growth Just right for a small garden. Very hardy. The flowers are an exceptionally lovely pink on long red wire-like stems.

2 to 3 ft., $\$ 1.50$

Malus Hopa Redflowering Crab. 12-15 ft. A remarkable tree -entirely covered with rose-colored blossoms in May. Fruit is red inside and out, adding to its attractiveness. Very hardy. 1 to 2 ft., $\$ 1.00 ; 2$ to 3 ft., $\$ 1.25 ; 4$ to 6 ft., $\$ 2.00$.

Malus Ioensis Plena (illustrated on cover). Handsomest of the doubles, pink flowers like huge clusters of small roses. Grows very bushy to about 12 feet.

2 to $3 \mathrm{ft} ., \$ 1.25 ; 3$ to 4 ft., $\$ 1.50$

Malus Kola. A crab of merit. Flowers pink and fruit green, 2 inches in diameter. A profuse bloomer.

3 to 4 ft., $\$ 1.25$

Malus Matthewi. Single flowers in profusion, rosepink in color and very fragrant; fruit quite large and fairly weights the branches to the ground, fine for jelly. 1 to 2 ft., $\$ 1.00$

Malus Ming Shing (Atrosanguinea). Ming Shing means "Stars of Heaven." For landscape effect this variety is the ultimate. The branches are determined to droop to the ground and should be let to do so, creating a pyramidal shrub. It is very vigorous and blooms when only inches high; when older, every twig is covered with carmine flowers. Not a leaf is in sight when the blooms appear-a gorgeous velvety red, and when the sun shines on them a scarlet sheen is suggested-a startling effect-very Oriental in its regal splendor.

3 to 4 ft., $\$ 1.25 ; 5$ to 7 ft., $\$ 1.50$

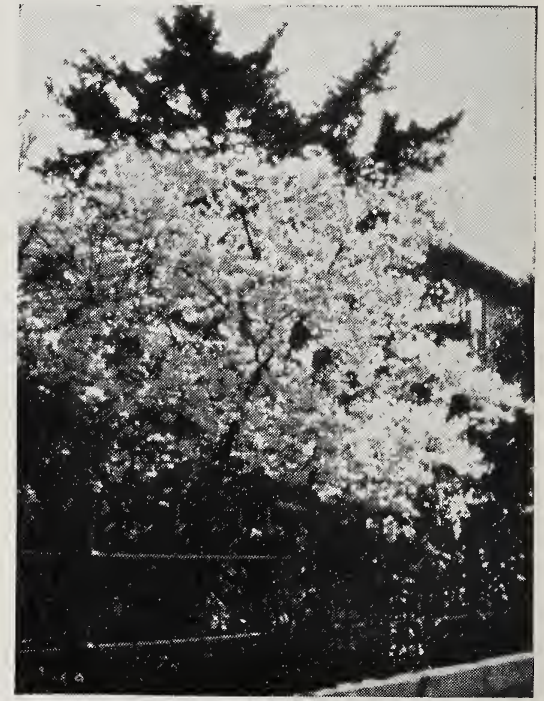

FAIRY QUEEN (Described on Page 4)

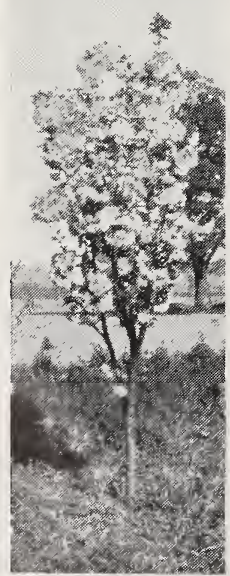

TAKASAGA SAKURA

Malus Purpuria. A form of the Jap-

anese Flowering Crab with rich purplish red flowers and fruit of the same color.

1 to 2 ft., $\$ 1.00$

Malus Spectabilis. A very fine Crab with pink bloom. We never have had enough of these.

1 to 2 ft., $\$ 1.00 ; 2$ to 3 ft., $\$ 1.25 ; 3$ to $4 \mathrm{ft}$., $\$ 1.75$

Malus Wah Mee (Scheideckeri). Means “The Modest Maiden." An upright, shapely tree. It fairly loads itself down with heavy masses of bright pink semi-double blossoms (see cut). Later it is loaded with myriads of naval orange colored apples the size of one's finger nail, which hang on until a heavy frost.

2 to $3 \mathrm{ft} ., \$ 1.00 ; 4$ to $5 \mathrm{ft} ., \$ 1.25 ; 6$ to $7 \mathrm{ft} ., \$ 2.50$

Subhirtella Pendula (Rosebud Weeping Cherry) (Shown on Page 2). The riot of color shown in this cut is true not only in this tree, but of the complete line of these wonderful trees. Those that already have them speak of them with pride. Very fine specimens of S. Pendula, 3 years old, grafted on 51/2-6 ft. standards, $\$ 4.50$

(On long distance shipments of over 300 miles add $20 \%$ for crating this tree) 


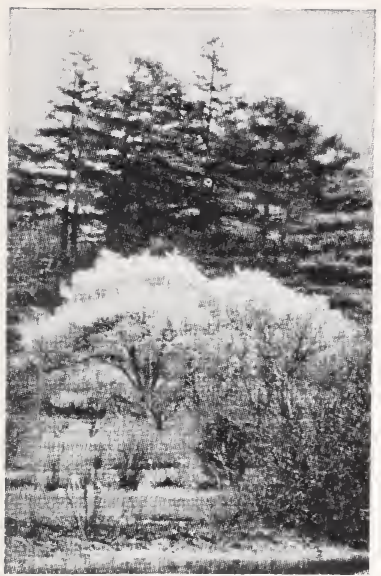

BENI HIGAN ZAKURA At Arnold Arboretum (Described on page 4)

\section{Japanese Flowering Apricots}

The Prunus Mum-e, or Flowering Apricot, is the first tree to blossom in the spring. Coming as it does with the daffodils, no words can express the thrill this beautiful Oriental tree gives, yet it is until now almost unknown to America.

“Beauty of Spring." Prumus Bliriana. A tree which grows to 15 feet. Foliage is a mellow pinkish red which holds throughout the season. The blossoms are a beautiful large double pink and very prolific in bloom. In our opinion these trees are worth many times their cost.

1 to $2 \mathrm{ft} ., 55 \mathrm{c} ; 3$ to $4 \mathrm{ft} ., \$ 1.25 ; 5$ to $6 \mathrm{ft} ., \$ 2.75 ; 8$ to $9 \mathrm{ft} ., \$ 4.00-\$ 5.00$

"The Iawn." Prunus Mun-e. Similar to the above in bloom, but earlier by a few days and foliage is a bright emerald green.

3 to $4 \mathrm{ft} ., \$ 2.00$

\section{Flowering Peaches}

Persica Burbanki. Luther Burbank created this beautiful tree. It is so outstanding that it blanks many others. We cut 200 limbs of bloom from our 3-year-old, and it seemed as bright as ever. A rare shade of Dutch Pink, very double. 4 to $5 \mathrm{ft} ., \$ 2.00$

Persica Rubra. Double dark red.

Specimen trees, 4 to $5 \mathrm{ft}$., $\$ 2.00$

Persica Rosea. Double pink.

3 to $4 \mathrm{ft} ., \$ 1.25$

A special list of additional flowering peach trees will be furnished upon request.

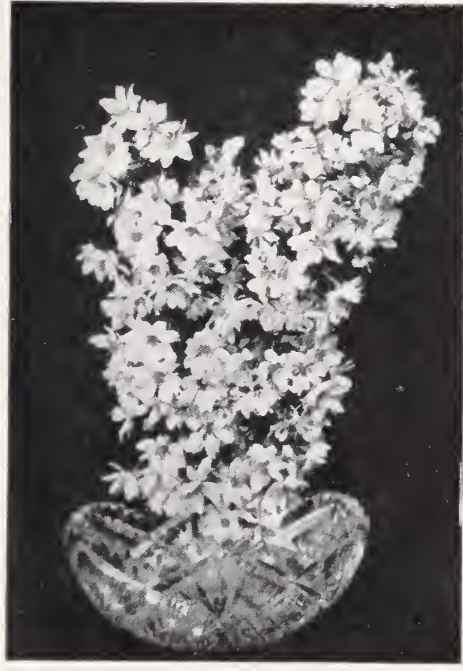

MALUS WAH MEE (Described on page 6)

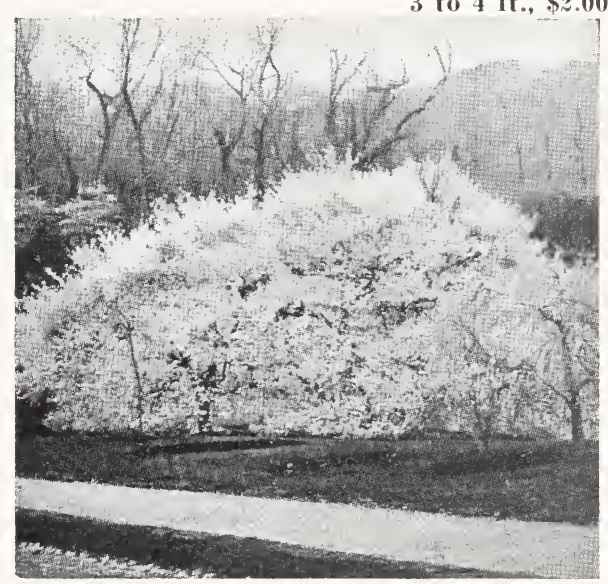

YOSHINO SAKURA (Described on Page 5) At Arnold Arboretum, showing the early blossom effect while native trees are bare.

\section{Evergreen Trees}

We are growing a few of these for our own grounds and have a surplus of these:

Irish Juniper. Columnal effect with sparkling green foliage, 30 to 36 in. B \& B..\$1.50

Picea pungens (Colorado Blue Spruce) 6 to 9 in. $\mathrm{B} \& \mathrm{~B}$

Cedrus deodara. Of the Hymalaya Mountains; blue-green; 27-30 in. $\mathrm{B}$ \& $\mathrm{B}$

1.75

\section{STRELT INI) PARIING TREES}

We sell a great many of these and will be glad to make suggestions. 


\section{FRENCH HYBRID LILACS}

As with our Oriental Flowering Trees, so with our Lilacs. We have selected and rejected until our present collection of these ever popular, fragrant shrubs includes the cream of the available varieties, mostly those of the justly famous originator, Victor Lemoine, of Nancy, France.

Our stock is healthy, vigorous and thrifty, mostly from 15 to 30 inches tall and well branched. Abbreviations: S, single; D, double; for originators: Lem. for Lemoine; Bal. for Baltet; Ell. for Ellwanger; Kla. for Klager.

Alexandre de Humboldt (D).

Magenta red (Lem.)............. $\$ 1.50$

Alphonse Lavell (S). Pure lilac color (Lem.)................ 1.50

Belle de Nancy (D). Large, satiny rose, white toward center (Lem.).

1.50

Bleuatre (S). Brightest blue of the singles (Bal.)............ 1.75

Colbert (D). Real purple. (Lem.).................................... 2.00

Coerulea Superba (S). This lilac meets with our approval. It is a good, bluish lilac (Ell.)........................... 1.50

Croix de Brahy (S). Pure shade of lilac. (Brahy)

1.50

Congo (S). Wine red (Lem.).

Comtesse Horace de Choiseul (D). Pure lilac color (Lem.).

Charles Joly (D). Dark violet purple. Best dark double (Lem.).

Decaisne (S). Most perfect of the bright blues (Lem.)

Doyen Keteleer (D). A splendid pink (Lem.) 1.50

Dr. Masters (D). Small flowers of bluish lilac, late bloomer (Lem.).

Erzherzog Johann (S). Another of the improved lilac shades (Anon.)...................... 1.00

Edouard Andre. Double clear rose. A wonderful color (Lem.)......................................

Emile Lemoine (D). Another of the best double pinks (Lem.).................................... 1.75

Edith Cavell (D). Pure white. Rated XXXX (Lem.) ............................................ 1.75

Furst Lichtenstein (S). Typical lilac. (Spaeth).

Georges Bellair (D). Pinkish-lilac (Lem.)... 1.50

Guizot (D). Purple (Lem.)................................ 1.50

Gloire de Moulins (S). Lilac blended to white (Anon.).

Gloire de la Rochelle (D). Rich magenta lilac (Anon.).

Grand Duc Constantine (D). Bluish-lilac. (Lem.)... Splendid Van Tol......................................

Jeanne d' Arc (D). A very wonderful white rated highly (Lem.)..
Hugo Koster (S). Lilac with reddish tint
Jacques Callot (S). Very large panicles of delicate rosy pink flowers. The individual flowers are very large (Lem.)................ 1.50

Kalama (S). Dark purple (Kla.)................... 2.00

Lamarck (D). Deep pinkish-lilac; very

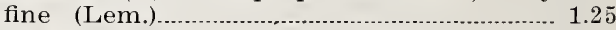

Louvainiensis (S). Pink. Splendid, but a shy bloomer............................................ 1.00

Lucie Baltet (S). Light copper shade; none like it (Bal.)............................................... 2.50

Maurice Barres (S). Blue. A wonderful lilac (Lem.)..................................................

Michael Buchner (D). Very double pale lilac blooms (Lem.)

Milton (S). Dark purple (Anon.)...................... 1.50

Mme. Francesque Morel (S). Deep magenta red, largest clusters yet produced. Rated perfect (Morel)

My Favorite (D). Dark, rich purple with corkscrew florets; very fine and unusual (Kla.).

Othello (S). Dark purple (Lem.)...................... 1.50

Pres. Grevy (D). A fine blue, not a regular bloomer (Lem.)...................................... 1.00

Pres. Fallieres (D). Purple with a pinkish blend, very fine (Lem.)................................. 1.75

Pres. Loubet (D). Dark magenta red (Lem.) 1.75

Princess Alexandra (S). White with clusters ten times larger than the common white lilac (Dougall)

Paul Thiron (D). Beautiful rich red (Lem.) 2.00

Philemon (S). One of the splendid dark, rich purples; small plants (Cochet)........... 2.50

Rubra Insignis (S). Dark red (Anon.)........... 1.50

R. W. Mills (S), Rich purple (Kla.)............... 2.00 
Sen. Volland (S). Rich pink (Lem.)

Souv. de Ludwig Spaeth (S). Dark wine red, large panicles (Spaeth) ........................ 1.00

Souv. de Rothpletz (D). Double heliotrope, strikingly beautiful (Anon.)

Syringa Chinensis (S). Pink tinged lilac. It produces masses of huge loose panicles to 18 inches long (a species)

Vestale (S). White, ranks at the top. It is early (Lem.)..

Volcan (S). Darkest purple, very choice. (Lem.).

Violetta (D). Darkest of the double purple, best of its color; smaller plants (Lem.)... 3.00

\section{Five Outstanding Lilacs}

Ruhm von Horstenstein (S). A distinct new shade among the tall, large-flowered lilacs. Buds open deep red, changing to lovely lilac. An excellent forcer, and even when forced the exceptionally large trusses have a delicious perfume, un equalled by any other lilac (Wilke).
Katherine Havemeyer (D). Pink flushed cobalt blue; enormous flowers of the most perfect shape, with broad, imbricated lobes. It is our opinion and the concensus of opinion of those seeing it here in bloom that it is the handsomest of lilacs (Lem.).

Emile Gentil (D). Deep delphinium blue. Best dark blue; no other lilac like it. (Lem.).

Mont-Blanc (S). White; very beautiful. Rated by Wister as the perfect lilac Panicles so large that one cannot believe one's own eyes (Lem.).

Miss Ellen Willmott (D). Snow white. Best double hyacinth flowered; late (Lem.).

\section{A Bonanza for the Lilac Lover}

\section{Prepaid}

Five one-year lilacs by post, prepaid, for $\$ 3.50$, or ten for $\$ 6.00$. Fine, healthy plants all named, from the choicest and newest varieties, our selection; all color's represented. No tender, greenhouse plants among them.

\section{Rare Shrubs}

Azalea liempferi. Torch Azalea, 8 to 12 in. \$ .75

Azalea hindodegiri. Earliest evergreen; a flaming crimson; 1 yr.

Aralea mollis. Beautiful shades of yellow. $1 \mathrm{yr}$.

Mronia arbutifolia. An excellent under shrub, to 4 or $6 \mathrm{ft}$. Covered every fall with bright red chokeberries; 18 to $36 \mathrm{in}$.

Berberis Wilsoni. New evergreen barberry, very fine foliage and much berried 12 to $18 \mathrm{in.}$

Caryopteris (Bluebeard Spirea). A splendid shrub of 30 to 36 in., covered during Sept. and Oct. with countless blue, feath ery flowers when other bloom is scarce. 18 to 24 in

Cashmere Spirea (Aitchisonia). A fern-leaf shrub of $8.10 \mathrm{ft}$. with huge creamy panicles at any and all times during spring and summer; 6 to $8 \mathrm{ft}$.

Ceonothus ryaneus. A new hybrid evergreen lilac; deepest imaginable blue. It grows quickly and flower's in unbeliev. able profusion; 3 to $4 \mathrm{ft}$.

Deutzia scabra plena. Double pink Deut zia, a splendid herlge plant; $4 \mathrm{ft}$.

Enkianthus canpanulatus. This is some times called the "Japanese Bell-flower." The bright, shiny green leaves turn to a brilliant red in autumn and remain on the plant until very late. In the spring it bears masses of bell-shaped pale orange and pale yellow flowers; attractive at all seasons; easy to grow. $1 \mathrm{yr}$. plants

Here are two little known shrubs that will please you immensely:

Forsytlia spectabilis. Deep orange in color and many times more prolific in bloom than other varieties. Large bushes 1.00
Forsythia primiulinus. Offered by us for the first time to American flower lover's It is the color of Primroses (light yellow) and as prolific as $F$. spectabilis; large bushes

Hibiscus pleno. Double flowered Althea Blooms from August to November continuously; blossoms are $2 \frac{1}{2}$ in. across and very handsome. A pyramidal shrub that will grow to 10 or $12 \mathrm{ft}$. Colors pink or red; 30 to 36 in.

Kalmia latifolia. The Evergreen Mountain Laurel; 6 to $9 \mathrm{in}$.

Kolkwitzia amabilis (Beautybush). (Illus trated on back cover.) Pink, May to June One of the late Dr. E. H. Wilson's and the Arnold Arboretum's choicest new introductions from China. Dr. Wilson says of it: "Most closely related to Abelia and Diervilla, it is hardier than either and in elegance and beauty exceeds both. It has successfully withstood the vagaries and severities of the New England climate, and each season for a number of years past has flowered freely in the Arnold Arboretum. Our best plant is about 6 feet tall and 5 feet through, and in early June is a mass of arching sprays of blos. som. The flowers are in pairs, and from 20-50 or more of them are borne in rounded cymose cluster's." We have priced these so low that every reader may have them, prepaid to their door. 20 to 30 in

For larger sizes write for quotations.

Leucothoe cateshaei. Drooping evergreen Laurel, graceful arching branches with lustrous green shining leaves that turn bronze in autumn. 12 to $24 \mathrm{in}$. 
Magnolia grandiflora. The Magnolia of the South. Dark green, shiny, large foliage, produces flowers 6 to 8 in. across in early fall; 6 to 10 in.

18 to 24 in

Lonicera Rubra. Redflowering Bush Honeysuckle, a beauty in bloom and in fall covered with red berries; $2 \mathrm{ft}$.

Oxedendrum arboreum. A very handsome medium sized tree or bush of $10 \mathrm{ft}$. or more. A mass of white flowers in summer; handsome foliage turning scarlet in autumn. 1 to $2 \mathrm{ft}$.

Pernettya speciosa. A low evergreen shrub with masses of berries in scarlet; 12 to 15 in

Photina villosa. A beautiful berry-bearing shrub, the bright red fruit persisting into the water. Leaves turn red in autumn; 1-yr. plants...

Pieris nitida (Mountain Fetterbush). A low spreading, graceful shrub, good for foundation plantings. White flowers in early spring; 1 to $2 \mathrm{ft}$.

Prunus cistena. A rare new hybrid purple leaf shrub, makes a wonderful contrast in the hedgerow. 3 to $4 \mathrm{ft}$...

Prunus Thunder Cloud. This is Luther Burbank's masterpiece, with foliage leaves measuring 6 inches long. Dark maroon in color, which it holds through out the entire season. In color nothing equals this in the floral world. Think of it-brightest autumn foliage from March to November. 5 to $6 \mathrm{ft}$., $\$ 2.008$ to $9 \mathrm{ft}$. 3.50

Punica. Double red Pomegranate. A rapid growing shrub with deep double scarlet flowers; blooms from June to October. $1 \frac{1}{2}$ to $2 \mathrm{ft}$.

Rhododendron maximum. Rosebay Rhodo. Pink tinged flowers in June. Its late blooming habit makes this species invaluable; 8 to 10 in.

Rhododendron catawbiense. Best, hardiest, all-round Rhodo. Rich red, tinged purple; 6 to $\delta$ in.

Rhus cotinus. Fringe Tree or Smoke Tree. A conspicuous spreading shrub of $8 \mathrm{ft}$, clustery round leaves overhung in summer by mist-like clouds of tiny light lavender flowers that give the impression of smoke. A valuable shrub; 15 to 20 in., $75 \mathrm{c} ; 24$ to 36 in.

Robina hispida. Flowers are a rich pink tinged with purple and hang in racemes similar to Wisteria. One of the most striking trees or large shrubs. 1 to $2 \mathrm{ft} .1 .25$

Robina Decaisenenna. Flowers light pink, pea-shaped; handsome spring flowering. Will make a fairly large tree, a fast grower. 1 to $2 \mathrm{ft}$.

Spirea trichocarpa. Handsome species introduced by Wilson from Korea. Abundant umbel-like racemes of large white flowers, strikingly different. 12 to 18 in., $60 \mathrm{c} ; 3$ to $4 \mathrm{ft}$.

Styrax Japonica. A new Japanese shrub or small tree with white bell-shaped flowers. 6 to 12 in..
Symphoricarpus chenaulti. Shrub 4 or $5 \mathrm{ft}$, originated at Arnold Arboretum. Fo. liage dainty, blossoms and berries pink. It's a wonderful creation; 15 to 18 in.....

Symphoricarpus vulgare. Coralberry. A delightful shrub for shady or sunny spots, with slender or arching branches covered with coral fruits until late winter. $3 \frac{1}{2}$ ft..

Viburnum tormentosum. Doublefile V. This is the V. that has created the furor in the flower magazines. Double rows of bloom along each stem; 12 to 15 in....

Wisteria multijuga rosea. Very rare. A pink-flowering Wisteria, like the long cluster purple one except in color; 2-yr. grafted plants.

Zanthorhiza apiifolia. Blooms dark, almost purple; cut-leaf foliage, very handsome. A very fine border plant for any situation; grows to about $3 \mathrm{ft}$. Sold in clumps

\section{Shrubs, Not So Rare, But Very Fine}

Abelia grandiflora. A beautiful evergreen shrub with glossy green foliage. It blooms in September, when bloom is scarce. Flowers are pink and white, resembling Trailing Arbutus; $3 \frac{1 / 2}{2}$ to $4 \mathrm{ft}$.

Cornus florida. White flowering Dogwood; 6 to 9 in., $25 \mathrm{c} ; 18$ to 24 in.......................... 1.00

Cydonia Japonica. Japanese Flowering

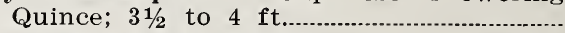

Deutzia, Pride of Rochester. White bloom, very fine; $3 \frac{1}{2}$ to $4 \mathrm{ft}$.

Hydrangea. French hybrids. Shades of pink; $3 \frac{1}{2}$ to $4 \mathrm{ft}$.

Laburnum. Golden Chain Tree; 9 to 12 in., 25c; large trees.......................... $\$ 1.00$ to 2.0

Philadelphus lemoine. Dense racemes of white flowers with delightful perfume. More prolific than old sorts; $3 \frac{1}{2} \mathrm{ft}$.........

Philadelphus virginal. A wonderful flowering shrub. The very best hybrid; $3 \frac{1}{2}$ to $4 \mathrm{ft}$.

Philadelphus avalanche. Finest of the Philadelphus; 12 to 15 in..

Pyracantha lelandi. Orange - red berries; large and bushy...

Spirea (Anthony Waterer). The dwarf red flowering sort. $1 \frac{1}{2}$ to $2 \mathrm{ft}$.

Spirea (Flora Plena). This is very rare and the most beautiful Spirea we know of. It blossoms like the Bridal Wreath, but the bloom consists of masses of large double cream-white blossom wreaths. $4 \mathrm{ft}$.

Spirea arguta. A free flowering early white, with foliage like Thunbergi and a Bridal Wreath like Van Houtte; $3 \frac{1}{2} \mathrm{ft}$. .75 Spirea van houtte. Bridal Wreath Spirea. Fine clumps, 4 ft..

'Tamarisk odessena. A shrub of peculiar charm. It has feathery foliage and a mass of mist-like pink blossoms in March. 5 to $7 \mathrm{ft}$..

Weigelia van houtte. Here is a new variety of this shrub. A beautiful pink

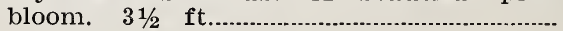




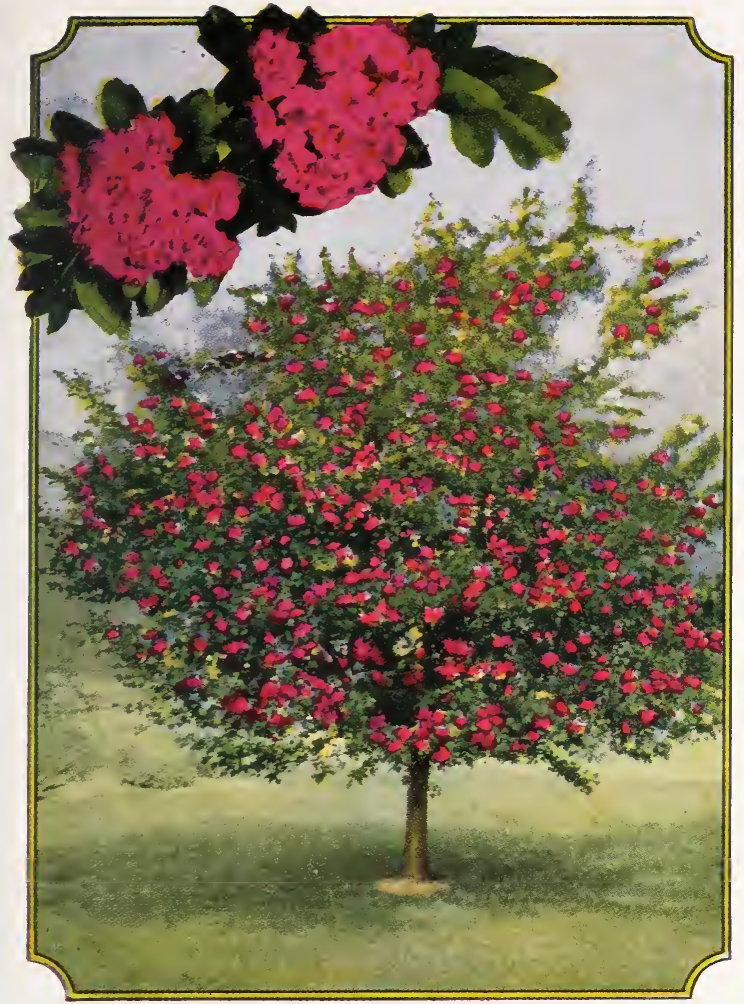

PAUL'S SCARIET HAWTHORN

\section{Hawthorn}

Paul's Double Scarlet. Not enough can be said of the beauty of this well known shrub or small tree with its spreading spiny branches; much prized for its double scarlet flowers in spring and dull red berries in fall and winter.

4 to $5 \mathrm{ft} ., \$ 1.00 ; 6$ to $7 \mathrm{ft}$., $\$ 1.50$

Double Pink. Same as above except that flowers are double pink instead of scarlet.

4 to $5 \mathrm{ft} ., \$ 1.25$

\section{Dogwood \\ (Cornus Rubra)}

Pink flowering. Blooms in early May as shown below; not as fast in growth as some, but each year grows handsomer and handsomer and soon becomes a bushy tree of $15 \mathrm{ft}$. and a better tree never grew.

$10-12$ in., $\$ 1.65 ; 20-24$ in., $\$ 3.00$

For the best of the new things both here and abroad, especially China and Japan, we are constantly searching and watching, as our success depends largely upon being first to propagate these items.

If you run across any trees or shrubs that you wish to procure, we invite you to correspond with us. If we haven't them, perhaps we can tell you where to procure them. We are not selfish enough to desire all of the nursery business.

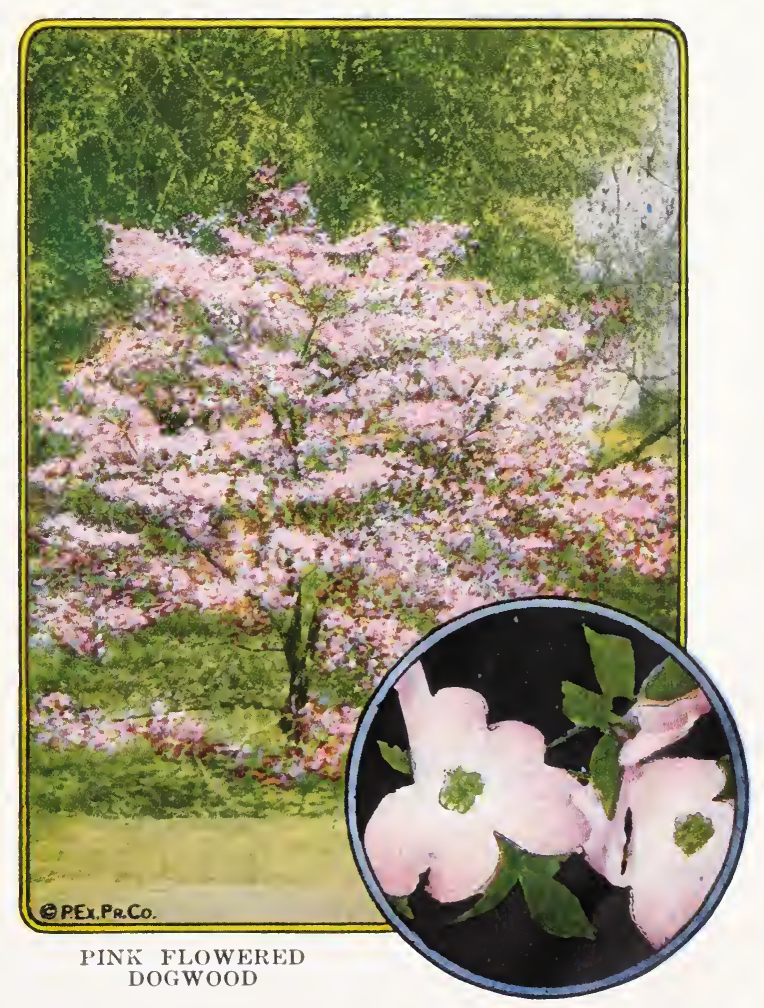




\section{French Hybrid Lilacs}

\section{Rare Flowering Shrubs}

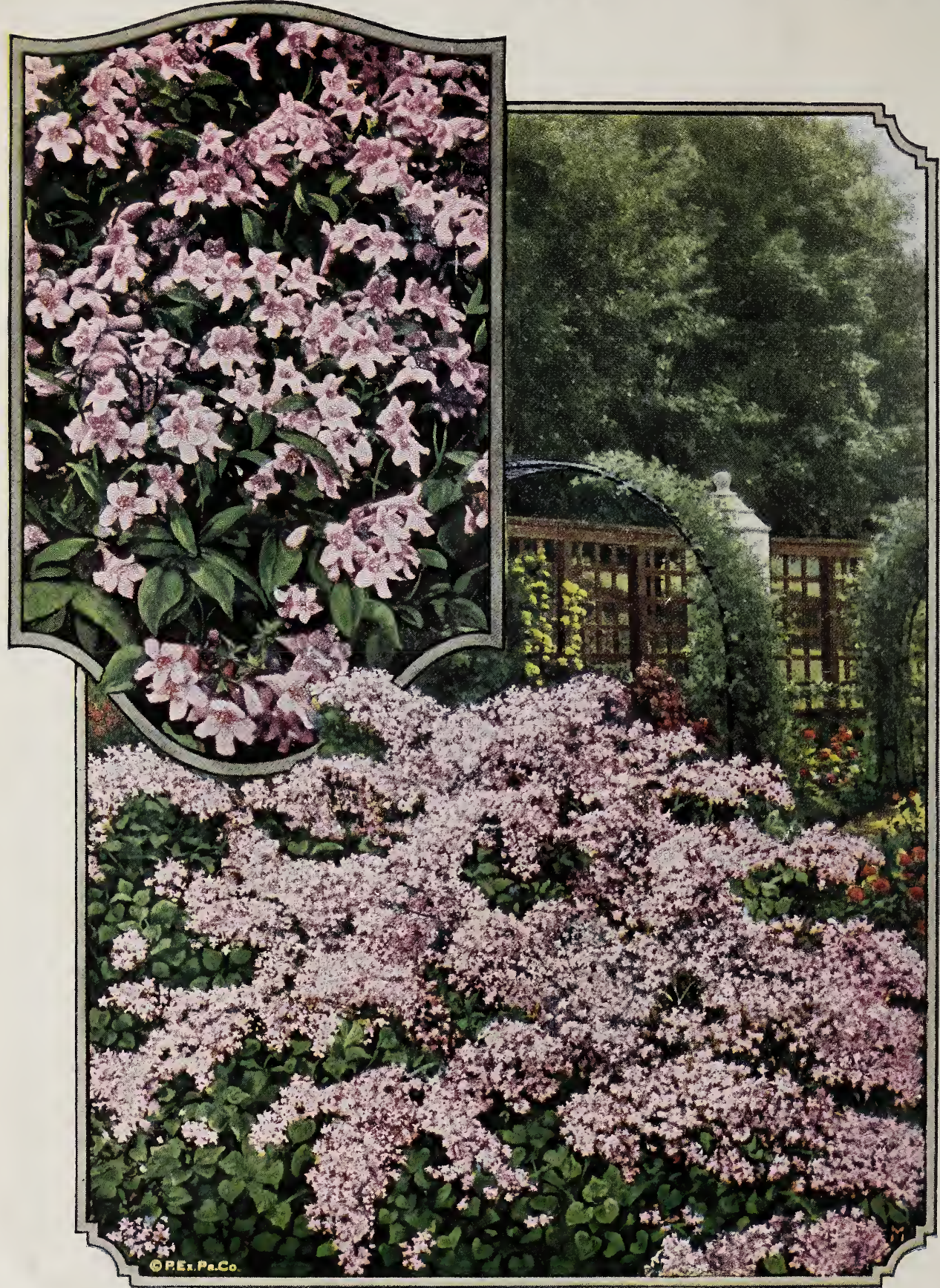

KOLKWITZIA AMABILIS (Described on Page 9) 